\title{
PENGGUNAAN PROBIOTIK PADA PAKAN PEMBESARAN IKAN BANDENG DALAM KERAMBA JARING APUNG DI LAUT
}

\author{
Abdul Malik Tangko*), Abdul Mansyur*), dan Reski**)
}

\begin{abstract}
ABSTRAK
Penelitian telah dilaksanakan di Teluk Labuange, Kabupaten Barru, Sulawesi Selatan selama 3 bulan. Penelitian menggunakan keramba jaring apung ukuran $1 \times 1 \times 1,2 \mathrm{~m}^{3}$ yang ditebari ikan bandeng ukuran 90-100 g/ ekor sebanyak 25 ekor/keramba. Sebagai perlakuan adalah penambahan probiotik (Haimix-S) dalam pakan masing- masing perlakuan $\mathrm{A}$ (kontrol tanpa probiotik); $\mathrm{B}(0,1 \%) ; \mathrm{C}(0,2 \%)$; dan $\mathrm{D}(0,3 \% \mathrm{~kg}$ pakan) masingmasing perlakuan terdiri atas tiga ulangan dalam rancangan acak lengkap. Hasil penelitian menunjukkan bahwa perlakuan $\mathrm{C}$ memberikan respon pertumbuhan harian terbaik, dan berbeda nyata $(P<0,05)$ dengan perlakuan $A, B$, dan $D$. Untuk sintasan semua perlakuan memberikan respon yang sama (tidak berbeda nyata) $(P>0,05)$. Sedang rasio konversi pakan terbaik diperoleh pada perlakuan $C$ dan $D$, dan berbeda nyata $(P<0,05)$ dengan perlakuan A dan B. Kisaran nilai beberapa variabel kualitas air yang diukur selama penelitian masih berada dalam batas- batas yang layak untuk menunjang pertumbuhan ikan uji.
\end{abstract}

\section{ABSTRACT: The used of probiotic on feed for milkfish grow-out. By: Abdul Malik Tangko, Abdul Mansyur, and Reski}

This experiment was conducted at Labuange Bay, Barru Regency, South Sulawesi for three months. The aims of this experiment was to find out the effect of the used probiotic (Haimix-S) in feed for milkfish grow-out cultured in floating cages in the sea. Completely Randomized Designed were used in this experiment, 12 floating cages each zise $1 \times 1 \times 1.2 \mathrm{~m}^{3}$ with mesh size 1.5 inch. Were stocked with 25 ind. of milkfish. Three dosages of probiotic (Haimix-S) were tested namely A without probiotic $(0.0 \%)$, $B(0.1 \%), C(0.2 \%)$, and $D(0.3 \%)$ per $\mathrm{kg}$. each treatment in triplicated. The results of this experiment showed that the best of daily growth rate were founded at the treatment $C$ and significantly different with the other treatments. The average of survival rate were $97.4-\%-100 \%$ and it was not significantly different $(P>0.05)$. There was also showed not significantly different $(P>0.5 \%)$ on feed conversio ratio between treatment $C$ and $B$, but there were significantly different $(P<0.05)$ with the treatment $A$ and $D$.

\section{KEYWORDS: probiotic, milkfish, grow- out, floating cage}

\section{PENDAHULUAN}

Dalam budi daya ikan secara intensif, pakan merupakan komponen biaya produksi yang paling tinggi yaitu $60 \%-70 \%$ dari biaya operasional. Hal ini disebabkan tingginya harga bahan baku pakan yang sampai saat ini sebagian besar masih diimpor. Salah satu alternatif yang dapat dilakukan untuk dapat menekan harga pakan adalah dengan mengurangi atau mengganti bahan baku impor dengan bahan baku lokal yang potensial. Beberapa bahan baku lokal yang tersedia secara memadai dan harganya relatif murah untuk dijadikan sebagai bahan pengganti di antaranya kepala udang, bungkil kelapa sawit,

*) Peneliti pada Balai Riset Perikanan Budidaya Air Payau, Maros

**) Universitas Hasanuddin, Makassar 
dedak, maupun limbah peternakan seperti darah hewan (Ahmad et al., 2000). Beberapa peneliti sebelumnya telah mencoba memanfaatkan bahan baku lokal tersebut di atas yang tersedia dalam jumlah yang memadai sebagai bahan pengganti bahan baku impor untuk pakan ikan, dan ternyata mampu menekan biaya pakan hingga $40 \%$ walaupun diakui bahwa kualitasnya relatif lebih rendah jika dibandingkan dengan kualitas bahan baku impor (Palinggi, 1993; Laining \& Rachmansyah, 2002). Salah satu penyebab rendahnya kualitas sebagian bahan baku lokal sebagai bahan pakan ikan diduga disebabkan bahan dasar yang berbeda serta proses penanganannya, mulai dari penyiapan bahan sampai pembuatan bahan baku yang belum sempurna sehingga dapat berpengaruh terhadap kualitas pakan yang dihasilkan, dan pada akhirnya akan berpengaruh terhadap pertumbuhan ikan/ organisme peliharaan.

Salah satu cara yang dapat dilakukan untuk meningkatkan kualitas pakan adalah dengan menambahkan bahan aditif berupa probiotik yang berisi mikroba pengurai ke dalam pakan yang dapat berfungsi untuk memperbaiki kualitas pakan dengan cara penguraian, sehingga dapat meningkatkan kecernaan pakan. Probiotik didefinisikan yaitu suplementasi sel mikroba utuh (tidak harus hidup) atau komponen sel mikroba pada pakan atau lingkungan hidupnya yang menguntungkan inangnya (Fuller, 1987 dalam Irianto, 2003; Gram et al., 1999 dalam Irianto, 2003). Selanjutnya dikatakan bahwa di dalam bidang akuakultur penggunaan probiotik bertujuan untuk menjaga keseimbangan mikroba, dan pengendalian patogen dalam saluran pencernaan, air serta lingkungan perairan melalui proses biodegradasi. Probiotik selain dapat digunakan untuk memperbaiki kualitas pakan juga dapat dipakai untuk memperbaiki kualitas air sehingga dapat meningkatkan kecernaan. Wang et al. (1999) dalam Irianto (2003) mengatakan bahwa Bacillus spp. sebagai prebion dapat digunakan untuk memperbaiki kualitas air melalui penyeimbangan populasi mikroba dan mengurangi jumlah patogen, dan secara bersamaan mengurangi penggunaan senyawa- senyawa kimia dan meningkatkan pertumbuhan serta kesehatan hewan inang.

Salah satu jenis probiotik yang saat ini banyak dipasarkan dengan nama dagang Haimix-S, diduga dapat digunakan sebagai suplemen yang dapat memperbaiki kualitas pakan, sehingga dapat meningkatkan kecerna- an pakan khususnya pada ikan. Palinggi (1993) mengatakan bahwa nilai kecernaan suatu bahan makanan menggambarkan kemampuan ikan dalam mencerna suatu makanan dan kecernaan itu sendiri ditentukan oleh kualitas makanan yang diberikan. Haimix-Sadalah salah satu jenis probiotik komersial yang dijual bebas di pasar. Bahan ini dominan mengandung bakteri Lactobacillus. Bakteri ini merupakan salah satu mikroorganisme fermentasi, sehingga bila terdapat dalam bahan makanan atau pakan maka akan dapat melakukan perbaikan mutu pakan sehingga dapat meningkatkan kecernaan yang pada gilirannya dapat meningkatkan pertumbuhan. Mikroorganisme ini juga banyak digunakan dalam industri makanan seperti pembuatan keju, yogurt dari susu, tempe, dan tape (Buckle et al., 1987). Selain itu, bakteri ini juga dapat menghambat pertumbuhan beberapa mikroorganisme patogen yang tidak dikehendaki di dalam bahan atau pakan (Petersen, 1971).

Penelitian penggunaan probiotik berupa Haimix-S bertujuan untuk mengetahui pengaruh penambahan probiotik dalam pakan dari bahan baku lokal terhadap pertumbuhan, sintasan, rasio konversi pakan, dan kecernaan pakan ikan bandeng. Hasil penelitian ini diharapkan sebagai bahan informasi dalam memperbaiki mutu pakan ikan bandeng dalam keramba jaring apung.

\section{BAHAN DAN METODE}

Penelitian telah dilaksanakan di Teluk Labuange Kabupaten Barru, Sulawesi Selatan selama tiga bulan, dengan menggunakan 12 unit keramba jaring apung ukuran $1 \times 1 \times 1,2 \mathrm{~m}^{3}$ yang terbuat dari jaring polietilen ukuran mata 1,5 inci. Masing- masing keramba diisi hewan uji berupa ikan bandeng ukuran $90-100 \mathrm{~g} /$ ekor sebanyak 25 ekor dan diset pada sebuah rakit di mana $20 \mathrm{~cm}$ dari permukaan keramba mencuat ke permukaan sehingga volume keramba adalah $1 \mathrm{~m}^{3}$. Sebagai perlakuan adalah pemberian probiotik berupa Haimix- $\mathrm{S}$ dengan komposisi seperti pada Tabel 1, ke dalam pakan yaitu: A kontrol tanpa probiotik $(0,0 \%), B(0,1 \%$, $\mathrm{C}(0,2 \%$, dan $\mathrm{D}(0,3 \% \mathrm{~kg}$ pakan). Masing- masing perlakuan terdiri atas tiga ulangan dan dirancang dalam bentuk acak lengkap (Gasperz, 1991). Pemberian probiotik dengan cara mencampur secara merata dengan bahan baku pakan, kemudian dicetak menggunakan mesin pencetak pakan, selanjutnya dikeringkan hingga siap diberikan kepada hewan uji. Pemberian pakan dilakukan dua kali sehari 
Tabel 1. Komposisi bahan dalam setiap gram Haimix- S/g

Table 1. Material composition of Haimix $-\mathrm{S} / \mathrm{g}$

\begin{tabular}{lc}
\hline \multicolumn{1}{c}{$\begin{array}{c}\text { Komposisi } \\
\text { Composition }\end{array}$} & $\begin{array}{c}\text { Kandungan } \\
\text { Ingredient }\end{array}$ \\
\hline Lactobacillus Powder & $4 \times 10^{5} \mathrm{cell}$ \\
Dextrose & $80 \mathrm{mg}$ \\
Ascorbic Acid & $30 \mathrm{mg}$ \\
Biodiastase & $15 \mathrm{mg}$ \\
Nicotinamide & $10 \mathrm{mg}$ \\
Lycine HCL & $10 \mathrm{mg}$ \\
Dibasic & $10 \mathrm{mg}$ \\
Dextrine & $10 \mathrm{mg}$ \\
Mononitrate & $2 \mathrm{mg}$ \\
Pantotenate & $2 \mathrm{mg}$ \\
Lactose & $1 \mathrm{mg}$ \\
Vitamin B & $1 \mathrm{mg}$ \\
Vitamin E & $1 \mathrm{mg}$ \\
Folic Asid & $0.5 \mathrm{mg}$ \\
Vitamin A & $2,500 \mathrm{lu}$ \\
Vitamin D & $200 \mathrm{lu}$ \\
\hline
\end{tabular}

Sumber (Source): Yastar International Co. Ltd Singen Pharmaceutical Works, Taiwan

pada pagi dan sore hari secara satiasi. Adapun analisis proksimat pakan uji dapat dilihat pada Tabel 2. Untuk menjaga agar sirkulasi air dalam keramba tetap lancar maka dilakukan pembersihan jaring secara kontinyu dengan cara menyikat jaring seminggu sekali, serta penggantian jaring secara periodik sekali sebulan. Selanjutnya jaring- jaring yang kotor dijemur dan dibersihkan untuk persiapan pemakaian berikutnya.

Peubah yang diamati meliputi: laju pertumbuhan harian dengan formula Hopkins (1992), sintasan dengan Effendie (1979), rasio konversi pakan dengan Sedgwick (1979), dan kecernaan pakan dengan Lovell (1981). Selain itu juga dilakukan pengamatan terhadap peubah kualitas air meliputi suhu, salinitas, oksigen terlarut, pH, kecepatan arus, dan kecerahan untuk mengetahui kelayakan habitat bagi kehidupan ikan uji. Sampling pertumbuhan dilakukan setiap 14 hari sekali dengan menggunakan timbangan OHAUS ketelitian $0,1 \mathrm{~g}$ sedang sintasan dan rasio konversi pakan dihitung pada akhir penelitian. Perhitungan FCR dalam penelitian ini diasumsikan bahwa semua pakan yang diberikan dapat dikonsumsi oleh ikan uji, karena sisa pakan yang sudah hancur di dasar keramba dan bercampur dengan partikel lainnya seperti kotoran ikan bahan organik serta pakan tidak dimakan dan terbawa arus keluar keramba sangat sulit dikumpulkan. Untuk mengetahui pengaruh perlakuan terhadap laju pertumbuhan harian, sintasan, rasio konversi pakan, dan kecernaan pakan terhadap hewan uji maka dilakukan analisis ragam dengan bantuan paket program statistik (M. Sustat). Bila diperoleh pengaruh yang nyata dari perlakuan maka dilakukan dengan uji lanjutan Tukey untuk mengetahui pengaruh perbedaan antar perlakuan. Sedang kelayakan habitat untuk mendukung kehidupan hewan uji dianalisis secara deskriptif.

\section{HASIL DAN BAHASAN}

\section{Pertumbuhan}

Hasil perhitungan terhadap laju pertumbuhan harian ikan uji diperoleh nilai tertinggi pada perlakuan $C$ yaitu 1,6\% hari; kemudian disusul masing- masing perlakuan $D$ yaitu $1,3 \%$ hari; $B$ yaitu 1,2\% hari; dan terendah pada perlakuan A tanpa pemberian probiotik yaitu $1,1 \%$ hari (Tabel 3). Hasil analisis ragam terhadap laju 
Tabel 2. Analisis proksimat pakan yang dicobakan selama penelitian

Table 2. Proximate analysis of the experiment diet were used during the experiment

\begin{tabular}{lrrrr}
\hline \multirow{2}{*}{$\begin{array}{c}\text { Komposisi } \\
\text { Composition (\%) }\end{array}$} & \multicolumn{3}{c}{$\begin{array}{c}\text { Perlakuan Haimix-S (\% kg pakan) } \\
\text { Treatment Haimix-S (\%) } \mathbf{k g} \text { of feed) }\end{array}$} \\
\cline { 2 - 5 } & A (0.0\%) & B (0.1\%) & C (0.2\%) & D (0.3\%) \\
\hline Protein (Crude protein) & 29.40 & 29.80 & 29.50 & 29.40 \\
Lemak (Crude fat) & 13.80 & 13.60 & 13.60 & 13.60 \\
Abu (Ash) & 11.80 & 12.10 & 12.10 & 11.90 \\
Air (Water) & 2.90 & 3.30 & 3.70 & 3.10 \\
Nitrogen Bebas Ekstrak & 44.70 & 44.43 & 44.65 & 44.91 \\
Nitrogen Free Ekstract & & & & \\
Serat kasar (Fibre) & 0.23 & 0.07 & 0.15 & 0.19 \\
Energi (kal./g)(Energy) (Cal./g) & $4,908.40$ & $4,872.60$ & $4,295.90$ & $4,985.60$ \\
\hline
\end{tabular}

Sumber:Laboratorium Nutrisi BRPBAP, Maros (2001)

Source: Nutrition Laboratory of BRPBAP, Maros (2001)

pertumbuhan harian menunjukkan bahwa perlakuan $C$ memperlihatkan respon pertumbuhan terbaik dan berbeda nyata $(P<0,05)$ dengan perlakuan lainnya. Sedang antara perlakuan $A, B$, dan $D$ memberikan respon pertumbuhan yang tidak berbeda nyata $(P>0,05)$ walaupun ada kecenderungan pertumbuhan ikan yang diberikan pakan mengandung probiotik lebih tinggi dari kontrol (Tabel 3). Hal ini menggambarkan bahwa pemberian probiotik berupa Haimix-Ske dalam pakan pada budi daya bandeng dalam keramba jaring apung di laut, dapat memberikan respon yang positif terhadap pertumbuhan. Rendahnya laju pertumbuhan harian yang diperoleh pada perlakuan dengan pemberian Haimix- $\mathbf{S}$ $0,1 \%$ diduga disebabkan jumlah bakteri pengurai Lactobacillus yang ditambahkan melalui pakan di dalam pencernaan makanan relatif sedikit, sehingga belum optimal di dalam

Tabel 3. Laju pertumbuhan harian, sintasan, dan rasio konversi pakan pada budi daya ikan bandeng selama percobaan

Table 3. Daily growth rate, survival rate and feed conversion ratio of milkfish culture during the experiment

\begin{tabular}{|c|c|c|c|c|}
\hline \multirow{2}{*}{$\begin{array}{l}\text { Parameter } \\
\text { Parameters }\end{array}$} & \multicolumn{4}{|c|}{$\begin{array}{l}\text { Perlakuan Haimix-S (\% kg pakan) } \\
\text { Treatment Haimix-S (\%/kg of feed) }\end{array}$} \\
\hline & $A(0,0 \%)$ & B (0.1\%) & C $(0.2 \%)$ & D $(0.3 \%)$ \\
\hline Lama pemeliharaan (hari) & & & & \\
\hline Rearing period (Days) & 56 & 56 & 56 & 56 \\
\hline Bobot awal (Initial weight) (g/ind.) & 104.3 & 89.7 & 96.6 & 92.3 \\
\hline Bobot akhir (Final weight ) (g/ ind.) & 193.5 & 179.6 & 225.8 & 195.2 \\
\hline $\begin{array}{l}\text { Laju pertumbuhan harian (\%/ hari) } \\
\text { Daily growth rate (\%/day) }\end{array}$ & $1.1^{\mathrm{a}}$ & $1.2^{\mathrm{a}}$ & $1.6^{\mathrm{b}}$ & $1.3^{\mathrm{a}}$ \\
\hline Sintasan (Survival rate) $(\%$ & $98.6^{a}$ & $100.0^{a}$ & $97.3^{a}$ & $98.6^{a}$ \\
\hline $\begin{array}{l}\text { Rasio konversi pakan } \\
\text { (Feed Conversion Ratio) (FCR) }\end{array}$ & $2.4^{\mathrm{a}}$ & $1.9^{a b}$ & $1.3^{c}$ & $1.6^{\mathrm{bc}}$ \\
\hline
\end{tabular}

Nilai dalam baris yang sama dan diikuti oleh huruf yang sama tidak berbeda nyata (The similar superscripts in the same row are not significantly different) $(\mathrm{P}<0.05)$ 
melakukan penguraian terhadap bahan pakan. Begitu juga dengan dosis 0,3\% justru didapatkan laju pertumbuhan harian yang sudah cenderung mulai menurun, hal ini diduga disebabkan oleh jumlah bakteri pengurai di dalam tubuh terlalu berlebihan, akibatnya terjadi penyerapan energi kembali oleh mikroorganisme Lactobacillus itu sendiri terhadap suplai makanan yang seharusnya dialokasikan oleh hewan uji untuk pertumbuhan, akibatnya pertumbuhan hewan uji menjadi lambat. Hal ini erat kaitannya dengan hasil penelitian Buckle et al. (1987) yang menyatakan bahwa mikroorganisme termasuk bakteri Lactobacillus juga membutuhkan suplai makanan yang cukup sebagai sumber energi dan penyedia unsur- unsur kimia dasar untuk pertumbuhan selnya. Konsep penerapan probiotik adalah memperbaiki keseimbangan mikroorganisme dalam sistem pencernaan (usus) inang sehingga dapat meningkatkan daya cerna.

\section{Sintasan}

Tingkat sintasan yang diperoleh selama penelitian berada pada kisaran 97,3\%sampai $100 \%$ tertinggi diperoleh pada perlakuan B (100\%); kemudian disusul masing-masing perlakuan A (98,6\%); D $(98,6)$; dan C $(97,3 \%)$. Namun hasil analisis ragam menunjukkan bahwa perlakuan yang dicobakan tidak memberikan pengaruh yang nyata $(P>0,05)$ terhadap sintasan ikan bandeng (Tabel 3). Hal ini diduga disebabkan ikan bandeng tahan terhadap penyakit, juga dukungan dari lingkungan perairan yang selama pemeliharaan berlangsung tidak mengalami perubahan atau goncangan drastis yang dapat menyebabkan ikan menjadi sakit atau mati. Hasil pengukuran peubah kualitas air selama penelitian berlangsung selalu dalam batas- batas yang layak untuk menunjang kehidupan ikan uji (Tabel 5). Hal ini diperkuat dengan hasil penelitian sebelumnya oleh Irianto (2003) yang mengatakan bahwa penggunaan probiotik sebagai suplemen dalam pakan selain dapat menekan mortalitas ikan peliharaan, juga dapat memperbaiki kualitas lingkungan perairan.

\section{Rasio Konversi Pakan}

Pascual (1984) mengatakan bahwa semakin rendah nilai rasio konversi pakan suatu pakan, maka semakin baik pakan tersebut karena hanya sedikit jumlah pakan yang dihabiskan untuk menghasilkan bobot tertentu dari suatu organisme. Selanjutnya Schmittou (1991), mengatakan bahwa tinggi rendahnya nilai rasio konversi pakan dapat dipengaruhi oleh beberapa faktor terutama kualitas dan kuantitas pakan, spesies ikan, ukuran ikan, serta kualitas perairan. Nilai rasio konversi pakan yang diperoleh selama percobaan perlangsung pada masing- masing perlakuan adalah $\mathrm{A}(2,4)$, $B(1,9), C(1,3)$, dan $D(1,7)$. Rasio konversi pakan terbaik diperoleh pada perlakuan $C$ yaitu 1,3; kemudian disusul perlakuan D 1,7; B 1,9; dan yang terburuk $A$ yaitu 2,4 . Hasil analisis ragam menunjukkan bahwa perlakuan $\mathrm{C}$ rasio konversi pakan pada 1,3 dan D tidak memperlihatkan perbedaan yang nyata $(P>0,05)$, namun keduanya berbeda nyata $(P<0,05)$ dengan perlakuan A. Sementara perlakuan B tidak berbeda nyata dengan perlakuan $\mathrm{D}$ dan A, tetapi memperlihatkan pengaruh yang sangat nyata $(P<0,01)$ dengan perlakuan $C$ terhadap rasio konversi pakan (Tabel 3 ). Hal ini menunjukkan bahwa pada dosis $0,2 \%$ dan $0,3 \%$ probiotik/ kg pakan kinerja mikroorganisme bakteri Lactobacillus adalah sama, dalam melakukan fermentasi untuk memperbaiki kualitas pakan sehingga dapat meningkatkan kecernaan pakan berjalan secara optimal.

\section{Kecernaan Pakan}

\section{Kecernaan bahan kering}

Hasil penelitian menunjukkan bahwa penambahan Haimix- S0,1 dan 0,2\% kg pakan pada budi daya bandeng dapat meningkatkan kecernaan bahan kering jika dibandingkan dengan perlakuan 0,3\%dan kontrol (Tabel 4). Hasil analisis ragam menunjukkan bahwa nilai kecernaan bahan kering pakan dengan penambahan Haimix- S 0,1 dan 0,2\%berbeda nyata $(P<0,05)$ dengan perlakuan lainnya. Nilai kecernaan bahan kering tertinggi diperoleh pada perlakuan C yaitu 40,3\% kemudian diikuti perlakuan B yaitu 36,3\% D yaitu 24,28\% dan terendah pada perlakuan tanpa probiotik yaitu $13,95 \%$ Tingginya nilai kecernaan bahan kering pada perlakuan B dan C ini (Tabel 4) sebagai akibat dari aktivitas mikroorganisme Lactobacillus di dalam memperbaiki mutu pakan, sehingga pakan mudah dicerna oleh ikan.

\section{Kecernaan protein}

Persentase kecernaan protein pakan oleh ikan bandeng tertinggi diperoleh pada perlakuan C yaitu $61,03 \%$ kemudian disusul perlakuan B $(54,93 \%)$, D $(53,93 \%)$, dan terendah pada kontrol $(49,19 \%)$. Hasil analisis ragam 
Tabel 4. Koefisien kecernaan bahan kering, protein, dan energi pada budi daya bandeng selama percobaan

Table 4. Apparent digestibility coefficient dry matter, protein, and energy on milkfish during the experiment

\begin{tabular}{cccc}
\hline \multirow{2}{*}{$\begin{array}{c}\text { Perlakuan } \\
\text { Treatment }\end{array}$} & \multicolumn{2}{c}{ Koefisien kecernaan (Apparent digestibility coefficient) (\%) } \\
\cline { 2 - 4 } & Bahan kering (Dry matter) & Protein (Protein) & Energi (Energy) \\
\hline A $(0.0 \%)$ & $13.95 \pm 6.47^{\mathrm{c}}$ & $49.19 \pm 4.46^{\mathrm{b}}$ & $40.24 \pm 4.53^{\mathrm{c}}$ \\
$\mathrm{B}(0.1 \% \mathrm{a}$ & $36.30 \pm 3.12^{\mathrm{a}}$ & $54.93 \pm 5.48^{\mathrm{ab}}$ & $55.17 \pm 2.04^{\mathrm{b}}$ \\
$\mathrm{C}(0.2 \% \mathrm{a}$ & $40.30 \pm 3.49^{\mathrm{a}}$ & $61.03 \pm 0.21^{\mathrm{a}}$ & $58.91 \pm 6.16^{\mathrm{a}}$ \\
$\mathrm{D}(0.3 \% \mathrm{a}$ & $24.28 \pm 6.60^{\mathrm{b}}$ & $53.93 \pm 2.27^{\mathrm{b}}$ & $50.02 \pm 3.49^{\mathrm{b}}$
\end{tabular}

Nilai dalam baris yang sama dan diikuti oleh huruf yang sama tidak berbeda nyata

The similar superscripts in the same row are not significantly different $(P>0.5)$

menunjukkan bahwa antara perlakuan B dan C tidak berbeda nyata $(P>0,05)$ namun perlakuan $C$ berbeda nyata $(P<0,05)$ dengan perlakuan $A$ dan D. Hal ini menunjukkan bahwa pemberian Haimix- S sebanyak 0,1 dan $0,2 \% \mathrm{~kg}$ pakan memberikan respon yang terbaik khususnya di dalam meningkatkan kecernaan protein. Tingginya nilai kecernaan protein pada perlakuan B dan C ini (Tabel 4) sebagai akibat dari aktivitas mikroorganisme di dalam memperbaiki mutu pakan, sehingga pakan mudah dicerna oleh ikan dan pada gilirannya respon pertumbuhan ikan bandeng pada perlakuan ini lebih tinggi

\section{Kecernaan energi}

Hasil penelitian menunjukkan bahwa kecernaan energi ikan bandeng tertinggi diperoleh pada perlakuan C yaitu 58,91\% kemudian disusul dengan perlakuan $B$ yaitu $55,2 \%$ D yaitu $50,1 \%$ dan A yaitu $40,24 \%$ Hasil analisis ragam menunjukkan bahwa antara perlakuan B dan C tidak berbeda nyata $(P>0,05)$, namun keduanya berbeda nyata dengan perlakuan lainnya. Hal ini menunjukkan bahwa pemberian Haimix-S sebanyak 0,1 dan $0,2 \% \mathrm{~kg}$ pakan memberikan respon yang terbaik khususnya di dalam meningkatkan kecernaan energi. Secara keseluruhan dapat dikatakan bahwa aktivitas mikroorganisme pada perlakuan $\mathrm{B}$ dan $\mathrm{C}$ dalam memperbaiki mutu pakan berjalan secara optimal, sehingga dapat meningkatkan kecernaan baik bahan kering, protein, maupun energi. Tingginya nilai kecernaan bahan kering, protein, dan energi itu sangat erat kaitannya dengan nilai rasio konversi pakan yang diperoleh, di mana semakin tinggi nilai kecernaan pakan maka nilai rasio konversinya juga akan semakin kecil.
Kondisi ini menyebabkan pertumbuhan ikan bandeng pada perlakuan Haimix- S 0,2\%lebih tinggi.

\section{Kualitas Perairan}

Wardoyo (1981) mengatakan bahwa untuk dapat mengelola sumber daya perikanan dengan baik, maka salah satu faktor yang perlu diperhatikan adalah kualitas airnya. Selanjutnya Boyd (1982) mengatakan bahwa suhu adalah merupakan salah satu variabel kualitas perairan yang perlu diperhatikan, karena akan banyak berpengaruh terhadap pertumbuhan dan kehidupan organisme peliharaan. Beberapa variabel kualitas air yang diamati selama penelitian ini berlangsung meliputi: salinitas, suhu, gas oksigen terlarut, $\mathrm{pH}$, kecerahan, dan kecepatan arus (Tabel 5).

Kisaran suhu yang dimonitor berada pada kisaran $27^{\circ} \mathrm{C}-30^{\circ} \mathrm{C}$, dan sangat layak untuk mendukung pertumbuhan ikan uji. Boyd (1982) mengatakan bahwa suhu yang optimal untuk pertumbuhan ikan berkisar antara $25^{\circ} \mathrm{C}-$ $32^{\circ} \mathrm{C}$. Selain itu, fluktuasi suhu yang terjadi juga sangat kecil, sehingga pengaruhnya terhadap kehidupan ikan uji dapat diabaikan.

Pengukuran salinitas yang dilakukan setiap hari berkisar antara 28,2-33,3 ppt (Tabel 5). Kisaran nilai tersebut layak untuk mendukung kehidupan dan pertumbuhan ikan uji, mengingat ikan bandeng mampu mentolerir perubahan salinitas mulai dari 0-158 ppt; sehingga areal budi dayanya pun cukup luas meliputi perairan tawar, payau, hingga ke perairan laut (Liao, 1991).

Gas oksigen terlarut yang dimonitor selama percobaan berada pada kisaran 3,0$4,5 \mathrm{mg} / \mathrm{L}$, dengan rata- rata harian $4,0 \mathrm{mg} / \mathrm{L}$. 
Tabel 5. Kisaran nilai peubah kualitas air yang dimonitor selama percobaan berlangsung

Table 5. The range of water quality variables were monitored during the experiment

\begin{tabular}{lcr}
\hline \multicolumn{1}{c}{ Variabel ( Variables) } & $\begin{array}{c}\text { Kisaran } \\
\text { Range }\end{array}$ & $\begin{array}{c}\text { Rata-rata } \\
\text { Average }\end{array}$ \\
\hline Salinitas (Salinity) (ppt) & $28.2-33.3$ & 33.2 \\
Gas oksigen terlarut (Dissolved oxygen) $(\mathrm{mg} / \mathrm{L})$ & $3.0-4.5$ & 4.0 \\
Suhu (Temperature) $\left({ }^{\circ} \mathrm{C}\right)$ & $27.0-30.0$ & 28.5 \\
$\mathrm{pH}$ & $8.4-8.9$ & 8.5 \\
Kecerahan (Transparency) $(\mathrm{m})$ & $2.3-6.0$ & 4.5 \\
Kecepatan arus (Current velocity) (cm/ dt.) & $12.0-40.0$ & 15.0 \\
\hline
\end{tabular}

Fluktuasi gas oksigen terlarut yang terjadi selama percobaan berlangsung sangat kecil, hal ini disebabkan karena kepadatan yang diaplikasikan hanya 25 ekor/ $\mathrm{m}^{3}$ serta pergantian jaring yang rutin secara periodik sekali dalam sebulan.

pH juga ikut berpengaruh terhadap pertumbuhan ikan, karena setiap jenis dan ukuran ikan mempunyai toleransi yang berbeda- beda terhadap perubahan $\mathrm{pH}$. Hasil penelitian sebelumnya oleh Wardoyo (1981) mengatakan bahwa kisaran $\mathrm{pH}$ yang layak untuk mendukung kehidupan organisme perairan adalah 5-9. Hasil pengukuran terhadap $\mathrm{pH}$ selama percobaan ini berlangsung berada pada kisaran 8,4-8,9 dengan rata- rata harian 8,5 dan layak untuk mendukung kehidupan ikan uji.

Kecerahan dapat dijadikan sebagai indikator kesuburan suatu perairan, walaupun kecerahan itu sendiri dapat dipengaruhi oleh beberapa faktor di antaranya partikel- partikel lumpur dan plankton. Kecerahan perairan yang diukur selama percobaan berada pada kisaran 2,3-4,5 m dengan rata- rata harian 4,5 m dan merupakan kecerahan yang ideal untuk lokasi budi daya ikan dengan sistem keramba jaring apung.

Khusus untuk budi daya ikan dengan sistem keramba jaring apung disarankan untuk ditempatkan pada perairan yang jernih, oleh karena pada budi daya ikan dengan sistem keramba jaring apung, pertumbuhan ikan sepenuhnya tergantung pada kualitas dan kuantitas pakan yang diberikan, sehingga kalau ditempatkan pada perairan yang keruh dikhawatirkan akan banyak pakan yang terbuang tidak termakan karena tidak terlihat oleh ikan utamanya pakan tenggelam. Selain itu, juga dapat mengganggu proses fotosintesis untuk penyediaan oksigen.

Kecepatan arus yang diperoleh berada pada kisaran $12-40 \mathrm{~cm} / \mathrm{dt}$. dengan rata- rata harian $15 \mathrm{~cm} / \mathrm{dt}$. dan masih layak untuk mendukung kehidupan ikan uji. Kecepatan arus yang tinggi $40 \mathrm{~cm} / \mathrm{dt}$, diperoleh hanya pada saat musim barat yang berlangsung selama 3 bulan dalam setahun mulai dari bulan November sampai akhir Februari setiap tahun. Ahmad et al. (1991) mengatakan bahwa kecepatan arus yang ideal untuk lokasi budi daya laut adalah $15 \mathrm{~cm} / \mathrm{dt}$.

\section{KESIMPULAN}

Pemberian Haimix- S dengan dosis $0,2 \% \mathrm{~kg}$ pakan pada budi daya bandeng dengan sistem keramba jaring apung memberikan respon yang terbaik terhadap laju pertumbuhan harian, rasio konversi pakan dan kecernaan pakan baik bahan kering, protein, maupun energi.

\section{DAFTAR PUSTAKA}

Ahmad, A., P.T. Imanto, Muchari, A. Basyarie, P. Sunyoto, B. Slamet, Mayunar, R. Purba, S. Diani, S. Rejeki, S.A. Pranowo, dan S. Murtiningsih. 1991. Petunjuk Teknis Operasional Pembesaran Ikan Kerapu dalam Keramba Jaring Apung. Badan Litbang Pertanian. Balai Penelitian Perikanan Budidaya Pantai Maros. 49 pp.

Ahmad, T., Rachmansyah., and N.N. Palinggi. 2000. The availability and use of fish feed local ingredients for humpback grouper grow- out. Proceeding of Regional Workshop on Management Strategies for Sustainable Sea Farming and Grouper Aquaculture. NACA, Bangkok, Thailand. 48 pp. 
Buckle, K.A., R.A. Edward, G.H. Fleet, and M. Wootton. 1987. Ilmu Pangan. Penerbit Universitas Indonesia. Jakarta. 623 pp.

Boyd, C.E. 1982. Water Quality Management for Pond Fish Culture. Elsevier Scientific Publishing Company, Amsterdam. 318 pp.

Effendie, M.I. 1979. Metode Biologi Perikanan. Cetakan I. Penerbit Yayasan Dewi Sri. Bogor. $112 \mathrm{pp}$.

Gasperz, V. 1991. Metode Perancangan Percobaan. Penerbit Armico Bandung. 632 pp.

Hopkins, K.P. 1992. Reporting Fish Growth. A Review of the Basic in Journal of World Aquaculture Society. p. 54-59.

Irianto, A.H. 2003. Probiotik Akuakultur. Cetakan I. Penerbit Gadjah Mada University Press. Bulaksumur Yogyakarta. 125 pp.

Lovell, R.T. 1981. Fish Feed Analisis and Fish Nutrition Studies. Departement of Fisheries and Alied Aquaqulture International Centre for Aquaqulture. Auburn University. $65 \mathrm{pp}$.

Liao, I.C. 1991. Milkfish culture in Taiwan. In Mc Vey, J. P. (eds.), CRC Handbook of Mariculture Vol.II. Finfish Aquaculture. CRC Press Inc. Boca Raton Florida. p. 91-115.

Laining, A. dan Rachmansyah. 2002. Komposisi nutrisi beberapa bahan baku lokal dan nilai kecernaan proteinnya pada ikan kerapu bebek, Cromileptis altivelis. J. Pen. Per. Indonesia, Edisi Akuakultur. 8(2): 45-51.

Pascual, F.P. 1984. Nutrien and Feeding of Sugfo, Penaeus monodon. UNDP/FAO Net work of Aqriculture Centre in Asia, Philippines, Doc. Ref. No.Aquatrain/ NACA/ 84089. 34 pp.

Petersen, C.S. 1971. Microbiology of Food Fermentation. Connection The AVI Publishing Co. USA. 282 pp.

Palinggi, N.N. 1993. Pengaruh Pergantian Bungkil Kedele dengan Ragi terhadap Pertumbuhan Pasca Larva Udang Windu. Tesis Program Pasca Sarjana. Institut Pertanian Bogor. 57 pp.

Sedgwick, R.W. 1979. Influence of dietary protein and energy on growth, food consumtion and food conversion efficiency in Penaeus merguiensis de Man. Aquaculture. 16: 7-30.

Schmittou, H.R. 1991. Cage culture. A method of fish production in Indonesia. FRDP, Central Research Institute for Fisheries Jakarta, Indonesia. 114 pp.

Wardoyo, S.T.H. 1981. Kriteria kualitas air untuk keperluan pertanian dan perikanan. Makalah Training Analisa Dampak Lingkungan, kerja sama PPLH- UNDP- PSL IPB Bogor, 19- 31 Januari 1981. 41 pp. 